\title{
Papers
}

\section{Randomised, double blind, placebo controlled study of fluticasone propionate in patients with moderate to severe chronic obstructive pulmonary disease: the ISOLDE trial}

\author{
P S Burge, P M A Calverley, P W Jones, S Spencer, J A Anderson, T K Maslen on behalf of the \\ ISOLDE study investigators
}

\begin{abstract}
Objectives To determine the effect of long term inhaled corticosteroids on lung function, exacerbations, and health status in patients with moderate to severe chronic obstructive pulmonary disease.

Design Double blind, placebo controlled study. Setting Eighteen UK hospitals.

Participants 751 men and women aged between 40 and 75 years with mean forced expiratory volume in one second $\left(\mathrm{FEV}_{1}\right) 50 \%$ of predicted normal.

Interventions Inhaled fluticasone propionate $500 \mu \mathrm{g}$ twice daily from a metered dose inhaler or identical placebo.

Main outcome measures Efficacy measures: rate of decline in $\mathrm{FEV}_{1}$ after the bronchodilator and in health status, frequency of exacerbations, respiratory withdrawals. Safety measures: morning serum cortisol concentration, incidence of adverse events. Results There was no significant difference in the annual rate of decline in $\mathrm{FEV}_{1}(\mathrm{P}=0.16)$. Mean $\mathrm{FEV}_{1}$ after bronchodilator remained significantly higher throughout the study with fluticasone propionate compared with placebo $(\mathrm{P}<0.001)$. Median exacerbation rate was reduced by $25 \%$ from 1.32 a year on placebo to 0.99 a year on with fluticasone propionate $(\mathrm{P}=0.026)$. Health status deteriorated by 3.2 units a year on placebo and 2.0 units a year on fluticasone propionate $(\mathrm{P}=0.0043)$. Withdrawals because of respiratory disease not related to malignancy were higher in the placebo group $(25 \% v$ $19 \%, \mathrm{P}=0.034)$.

Conclusions Fluticasone propionate $500 \mu \mathrm{g}$ twice daily did not affect the rate of decline in $\mathrm{FEV}_{1}$ but did produce a small increase in $\mathrm{FEV}_{1}$. Patients on fluticasone propionate had fewer exacerbations and a slower decline in health status. These improvements in clinical outcomes support the use of this treatment in patients with moderate to severe chronic obstructive pulmonary disease.
\end{abstract}

\section{Introduction}

Chronic obstructive pulmonary disease is a leading cause of morbidity and mortality worldwide, ${ }^{12}$ and its prevalence is rising. ${ }^{3}$ It occurs predominantly in tobacco smokers and is characterised by an increase in the annual rate of decline of forced expiratory volume in one second $\left(\mathrm{FEV}_{1}\right){ }^{4}$ As lung function deteriorates, substantial changes in general health occur. ${ }^{5}$ Smoking cessation reduces the rate of decline in $\mathrm{FEV}_{1}$ in people with this disease, ${ }^{6}$ but no pharmacological intervention has been shown to modify the progression of disease or the associated decline in health status.

In at least $10 \%$ of patients with stable chronic obstructive pulmonary disease $\mathrm{FEV}_{1}$ will increase significantly after oral prednisolone. ${ }^{7} \mathrm{~A}$ large, retrospective, open study reported a reduction in the rate of decline of $\mathrm{FEV}_{1}$ in those taking oral corticosteroids. Recently, two studies over three years of inhaled budesonide $800 \mu \mathrm{g}$ in mild to moderate chronic obstructive pulmonary disease found no effect of treatment on the rate of decline in $\mathrm{FEV}_{1}{ }^{9}{ }^{10}$ Clinical outcomes such as exacerbations, however, were infrequent and health status either showed no benefit of budesonide ${ }^{9}$ or was not assessed..$^{10}$

The inhaled steroids in obstructive lung disease in Europe (ISOLDE) study was designed to test the effect of inhaled fluticasone propionate $500 \mu \mathrm{g}$ twice daily on the rate of decline of $\mathrm{FEV}_{1}$ and other relevant clinical outcomes.

\section{Participants and methods}

\section{Participants}

Eighteen UK hospitals participated. Patients were current or former smokers aged 40-75 years with non-asthmatic chronic obstructive pulmonary disease. Baseline $\mathrm{FEV}_{1}$ after bronchodilator was at least 0.8 litres but less than $85 \%$ of predicted normal, and the ratio of $\mathrm{FEV}_{1}$ to forced vital capacity was less than $70 \%$. Previous use of inhaled and oral corticosteroids was permitted. Patients were excluded if their $\mathrm{FEV}_{1}$ response to $400 \mu \mathrm{g}$ salbutamol exceeded $10 \%$ of predicted normal, they had a life expectancy of less than five years from concurrent diseases, or they used $\beta$ blockers. Nasal and ophthalmic corticosteroids, theophyllines, and all other bronchodilators were allowed during the study.

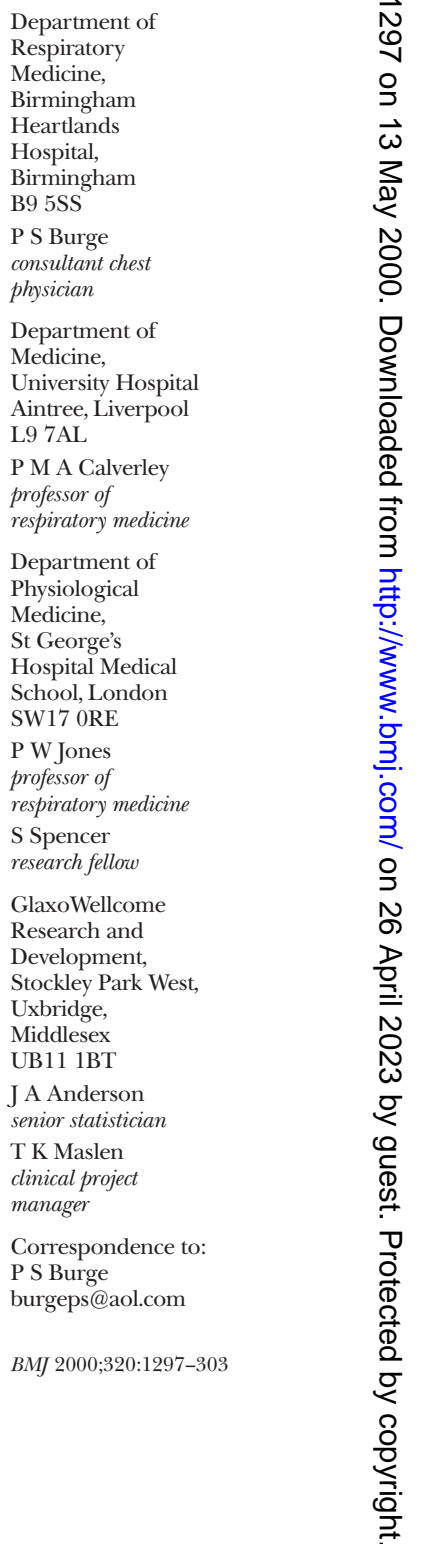


The protocol was approved by each centre's local ethical committee and patients provided written informed consent.

\section{Trial design}

Patients were recruited between 1 October 1992 and 31 March 1995. Eligible patients entered an eight week run-in period after withdrawal from any oral or inhaled corticosteroids. After clinic visits at 0,4 , and 8 weeks (visits 0,1 , and 2 , respectively) patients were randomised to receive either fluticasone propionate 500 $\mu \mathrm{g}$ or an identical placebo twice daily administered from a metered dose inhaler and with a spacer device by using 10 tidal breaths after each of two actuations. We used a computer generated allocation schedule stratified by centre (block size of six). Patients were randomised sequentially from a list comprising treatment numbers only. Throughout the trial patients used salbutamol (100 $\mu \mathrm{g} /$ puff) or ipratropium bromide (40 $\mu \mathrm{g} /$ puff), or both, for symptomatic relief.

Before the double blind phase, and if not contraindicated, patients received oral prednisolone 0.6 $\mathrm{mg} / \mathrm{kg} /$ day for 14 days, after which spirometry was performed. These data were used to test whether the acute corticosteroid response could predict those patients who would benefit from long term inhaled corticosteroids. During the three year double blind phase, participants visited a clinic every three months for spirometry, recording of exacerbations, and safety assessments.

The primary end point was the decline ( $\mathrm{ml} /$ year) in $\mathrm{FEV}_{1}$ after bronchodilator. About 450 patients with two or more measurements of $\mathrm{FEV}_{1}$ during treatment were required to detect a treatment difference of $20 \mathrm{ml} /$ year, assuming a linear decline and a SD of $75 \mathrm{ml} /$ year, with $80 \%$ power. Other key end points were frequency of exacerbation, changes in health status, withdrawals because of respiratory disease, morning serum cortisol concentrations, and adverse events.

\section{Measurements}

Spirometry measurements were recorded by well trained staff using a standardised procedure on new Sensormedics 2130D spirometers. Quality control included a computer generated check against the ATS criteria $^{11}$ and a central manual check for acceptability and reproducibility for all measurements, resulting in standards comparable with the lung health study. ${ }^{12}$ Visits were rescheduled to four weeks after any respiratory infections or exacerbations of the disease.

An exacerbation was defined as worsening of respiratory symptoms that required treatment with oral

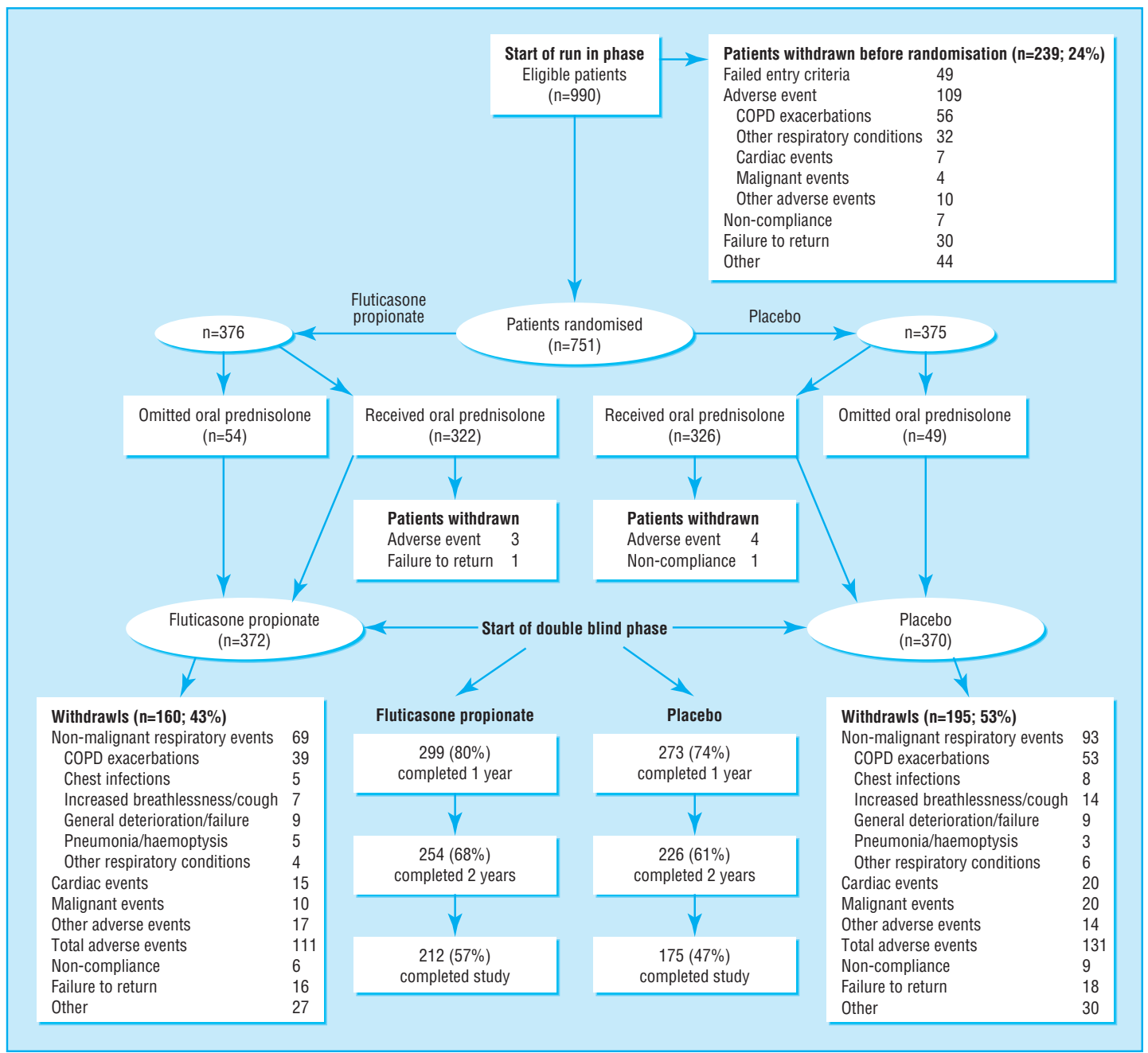

Fig 1 Profile of number of patients at each phase of study 
corticosteroids or antibiotics, or both, as judged by the general practitioner; specific symptom criteria were not used. Patients were withdrawn from the study if the number of exacerbations that required corticosteroids exceeded two in any three month period.

Health status was assessed at baseline and six monthly thereafter by using the disease specific St George's respiratory questionnaire (SGRQ) ${ }^{13}$ This questionnaire is sensitive to changes in treatment. ${ }^{14} \mathrm{~A}$ change in total score of four or more units represents a clinically important change in the patient's condition. Serum cortisol concentrations were measured before randomisation (baseline) and every six months during treatment. Samples were taken between 8 am and 10 am and were analysed with the ELISA-Boehringer Mannheim ES700 method.

At each visit patients were questioned about smoking status. Non-smoking was checked with exhaled carbon monoxide and urinary cotinine measurements. Self declared non-smokers were classified as smokers if cotinine was $>40 \mathrm{ng} / \mathrm{ml}$ or carbon monoxide was $>10 \mathrm{ppm}$ at two visits. For analysis patients were categorised as continuous smokers, continuous former smokers, or intermittent smokers during the study.

\section{Statistical analysis}

Analyses for each parameter included all randomised patients with at least one valid measurement. To use all patient data we adopted the mixed models approach ${ }^{15}$ for the primary analysis of $\mathrm{FEV}_{1}$ and total score. This is the most suitable technique for estimating rates of change, with allowance for the correlation structure of repeated measures data. Regression estimates were adjusted for patient differences in the number of observations contributing to the model and for variances within patients. ${ }^{16}$ Fixed effects were time and five covariates: baseline value centre, age, sex, and smoking status. Baseline $\mathrm{FEV}_{1}$ was the mean at four and eight weeks of the run-in period-that is, at least four weeks after withdrawal of corticosteroids. Subject effects were assumed to be random. The treatment by time interaction tested for a differential treatment effect on the rate of change in $\mathrm{FEV}_{1}$ or respiratory questionnaire score. The model for $\mathrm{FEV}_{1}$ also included a treatment main effect to help to account for the early non-linear treatment changes. Measurements at the end of the prednisolone trial were excluded from the model of decline in $\mathrm{FEV}_{1}$. $\mathrm{FEV}_{1}$ was also compared by using analysis of covariance after 3 , $6,12,24$, and 36 months to investigate treatment differences over time.

Patient exacerbation rates were calculated as the exacerbation number per treatment days and extrapolated-interpolated to a number per treatment year. The Wilcoxon rank sum test, ${ }^{17}$ stratified by centre,tested for treatment differences.

Fisher's exact test compared treatment withdrawals due to respiratory causes. These included any non-malignant lower respiratory diseases. Analysis of covariance compared data on log transformed serum cortisol concentration during treatment, adjusted for baseline. Tests were two sided, with a 5\% significance level.

\section{Results}

\section{Patient demographics}

Of the 751 patients randomised, 376 received fluticasone propionate and 375 placebo (figure 1). During the double blind phase, 160 patients (43\%) withdrew from the fluticasone propionate group and 195 patients $(53 \%)$ from the placebo group, the commonest reason being frequent exacerbations of chronic obstructive pulmonary disease. Mean $\mathrm{FEV}_{1}$ at visit two was $160 \mathrm{ml}$ lower in patients who withdrew from placebo compared with those who did not withdraw (1.30 litre $v 1.46$ litre); patients who withdrew from fluticasone propionate had a $40 \mathrm{ml}$ higher FEV compared with those who did not withdraw (1.44 litre $v 1.40$ litre). Treatment groups were well matched at baseline (table 1).

\section{Changes in FEV $_{1}$}

There was a fall in mean $\mathrm{FEV}_{1}$ after bronchodilator during the the run-in (placebo $75 \mathrm{ml}$, fluticasone propionate $65 \mathrm{ml}$ ) (fig 2). The effect was greater in patients who withdrew from inhaled corticosteroids at run-in (89 $\mathrm{ml}$ compared with $47 \mathrm{ml}$ in the steroid naive group). After oral prednisolone there was a $60 \mathrm{ml}$ (SD $170 \mathrm{ml}$ ) improvement in mean $\mathrm{FEV}_{1}$ after bronchodilator in both treatment groups. Subsequently mean $\mathrm{FEV}_{1}$ declined gradually in the fluticasone propionate group whereas in the placebo group it fell within three months to values before prednisolone treatment.

The annual rate of decline in $\mathrm{FEV}_{1}$ was $59 \mathrm{ml} /$ year in the placebo group and $50 \mathrm{ml} /$ year in the fluticasone propionate group $(\mathrm{P}=0.16)$ (table 2$)$. This small difference in slopes was uninfluenced by smoking status, age, sex, or $\mathrm{FEV}_{1}$ response to the oral corticosteroid trial. The predicted mean $\mathrm{FEV}_{1}$ at three and 36 months in

Table 1 Baseline characteristics of randomised population. Figures are means (SD) unless stated otherwise

\begin{tabular}{|c|c|c|}
\hline & Placebo & Fluticasone propionat \\
\hline No of patients randomised & 375 & 376 \\
\hline Age (years) & $63.8(7.1)$ & $63.7(7.1)$ \\
\hline Women & 97 & 94 \\
\hline Body mass index $\left(\mathrm{kg} / \mathrm{m}^{2}\right)$ & $24.9(4.7)$ & $24.5(4.8)$ \\
\hline Evidence of atopy* & 91 & 103 \\
\hline Smoked throughout trial & 147 & 137 \\
\hline Former smoker throughout trial & 172 & 176 \\
\hline Smoking pack years at randomisation $†$ & $44(34)$ & $44(30)$ \\
\hline Previous use of regular inhaled corticosteroids & 214 & 192 \\
\hline \multicolumn{3}{|l|}{ Lung function at visit $0 \ddagger$ : } \\
\hline After salbutamol $(400 \mu \mathrm{g}) \mathrm{FEV}_{1}$ & $1.40(0.48)$ & $1.42(0.47)$ \\
\hline As $\%$ predicted normal & $50.0 \%(14.9 \%)$ & $50.3 \%(14.9 \%)$ \\
\hline Change in $\mathrm{FEV}_{1}$ after salbutamol $(400 \mu \mathrm{g})$ & $0.13(0.10)$ & $0.13(0.10)$ \\
\hline As $\%$ predicted normal & $4.4 \%(3.4 \%)$ & $4.4 \%(3.5 \%)$ \\
\hline After salbutamol $(400 \mu \mathrm{g}) \mathrm{FVC}$ & $3.29(0.80)$ & $3.37(0.82)$ \\
\hline After salbutamol $(400 \mu \mathrm{g}) \mathrm{FEV}_{1}: \mathrm{FVC}$ & $43.0 \%(11.0 \%)$ & $43.0 \%(12.0 \%)$ \\
\hline \multicolumn{3}{|l|}{ Baseline (average of visit 1 and 2 ) $\S$ : } \\
\hline $\mathrm{FEV}_{1}$ before bronchodilator & $1.23(0.47)$ & $1.25(0.44)$ \\
\hline $\begin{array}{l}\mathrm{FEV}_{1} \text { after bronchodilator (salbutamol } 400 \mu \mathrm{g} \text { and } \\
\text { ipratropium bromide } 80 \mu \mathrm{g} \text { ) }\end{array}$ & $1.40(0.49)$ & $1.42(0.47)$ \\
\hline Respiratory questionnaire total scoren & $49.9(17.4)$ & $47.7(17.6)$ \\
\hline
\end{tabular}

$\mathrm{FEV}_{1}=$ forced expiratory volume in one second in litres; $\mathrm{FVC}=$ forced vital capacity.

*Atopy was defined as being positive response to skin prick testing with common inhalant allergens

Missing data—placebo: 14; fluticasone propionate: 20

†Missing data-placebo: 37; fluticasone propionate: 16

†Missing data-placebo: 4; fluticasone propionate: 3 .

§Missing data-placebo: 1 ; fluticasone propionate: 0

ๆScore of zero indicates no health impairment and 100 represents worst possible score. Missing

data—placebo: 8; fluticasone propionate: 7 . 


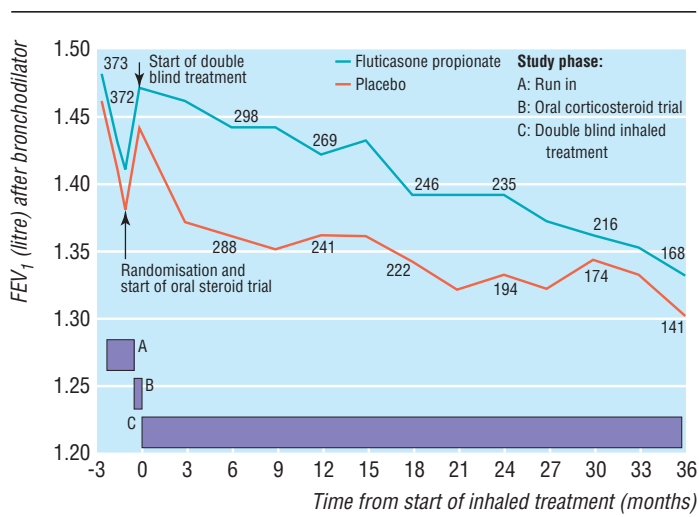

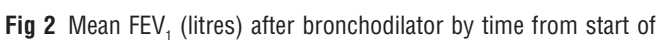
double blind treatment. Numbers reflect patients with valid readings at each time point. Measurements within four weeks of exacerbation are excluded. Direct comparisons of $\mathrm{FEV}_{1}$ means at each time point are not possible because fewer patients remained in the study as it progressed

the fluticasone propionate group was $76 \mathrm{ml}$ and 100 $\mathrm{ml}$ higher, respectively, than in the placebo group (mixed effects model $\mathrm{P}<0.001$ ). The analysis of covariance showed that $\mathrm{FEV}_{1}$ in the fluticasone propionate group was higher than in the placebo group by at least $70 \mathrm{ml}$ at each time point $(\mathrm{P} \leqslant 0.001)$. There was no significant relation between $\mathrm{FEV}_{1}$ response to oral corticosteroid or fluticasone propionate $(\mathrm{P}=0.056)$.

\section{Exacerbations}

The median yearly exacerbation rate was lower in the fluticasone propionate group (0.99 per year) compared with the placebo group (1.32 per year), a reduction of $25 \%$ in those receiving fluticasone propionate $(\mathrm{P}=0.026)$.

\section{Health status}

At baseline the total respiratory questionnaire score was not significantly different between treatment groups (table 1), and it did not change significantly over the first six months of treatment (placebo: up 1.2 (SD 11.9); fluticasone propionate: down 0.5 (SD11.8); $\mathrm{P}=0.09$ ). Thereafter it increased (that is, health status declined) over time (figs 3 and 4). This increase was linear $(\mathrm{P}<0.0001)$. The respiratory questionnaire score worsened at a faster rate $(\mathrm{P}=0.004)$ with placebo (3.2 units/year) than with fluticasone propionate (2.0 units/year).

\section{Withdrawals}

More patients in the placebo group than in the fluticasone propionate group withdrew because of respiratory disease that was not associated with malignancy $(25 \%$ v 19\%, respectively; $\mathrm{P}=0.034)$.

\section{Safety}

Reported events were similar between treatments (table 3), except for a slightly higher incidence of events related to inhaled glucocorticoid in the fluticasone propionate group.

There was a significant $(\mathrm{P} \leqslant 0.032)$ yet small decrease in mean cortisol concentrations with fluticasone propionate compared with placebo (table 4). No more than $5 \%$ of patients on fluticasone propionate had values below the normal range during the study at any time. No decreases were associated with any signs or symptoms of hypoadrenalism or other clinical effects.

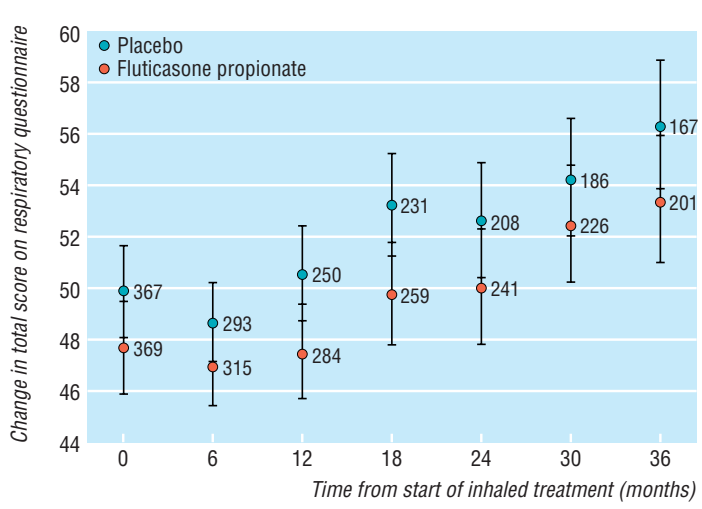

Fig 3 Effect of treatment on decline in health indicated by increasing total scores on respiratory questionnaire (means $(95 \%$ confidence intervals) calculated from analyses of covariance). Numbers at each assessment indicate number of patients for whom measurements of health status were available at that visit. Direct comparisons of respiratory questionnaire scores at each time point are not possible because fewer patients remained in the study as it progressed

Table 2 Results from efficacy analyses. Mixed effects model analyses adjusted for covariates and Wilcoxon Mann-Whitney test adjusted for centre

\begin{tabular}{|c|c|c|c|c|}
\hline Efficacy parameter & Placebo & $\begin{array}{l}\text { Fluticasone } \\
\text { propionate }\end{array}$ & $\begin{array}{l}\text { Treatment difference between drug and } \\
\text { placebo }(95 \% \mathrm{Cl})\end{array}$ & $P$ value \\
\hline \multicolumn{5}{|l|}{$\mathrm{FEV}_{1}$ after bronchodilator: } \\
\hline No of patients & $325^{\star}$ & $339^{*}$ & & \\
\hline Mean change in $\mathrm{FEV}_{1}$ ml/year (SE) & $-59(4.4)$ & $-50(4.1)$ & $9(6.0)(-3$ to 20$)$ & 0.161 \\
\hline Predicted $\mathrm{FEV}_{1}$ at 3 months & 1.37 & 1.44 & $0.076(0.056$ to 0.097$)$ & $<0.001$ \\
\hline Predicted $\mathrm{FEV}_{1}$ at 3 years & 1.20 & 1.30 & $0.100(0.064$ to 0.135$)$ & $<0.001$ \\
\hline \multicolumn{5}{|l|}{ Health status: } \\
\hline No of patients & $291^{*}$ & $309^{*}$ & & \\
\hline Mean change in questionnaire score (SE) (units/year) & $3.17(0.31)$ & $2.00(0.29)$ & $-1.17(0.40)(-1.95$ to -0.39$)$ & 0.004 \\
\hline \multicolumn{5}{|l|}{ Annual exacerbation rate: } \\
\hline No of patients & 370 & 372 & & \\
\hline Mean (SD) rates & $1.90(2.63)$ & $1.43(1.93)$ & & \\
\hline Median (range) rates & $1.32(0$ to 30$)$ & $0.99(0$ to 26$)$ & $-0.3(-0.4$ to 0.0$) \dagger$ & 0.026 \\
\hline
\end{tabular}

$\mathrm{FEV}_{1}=$ forced expiratory volume in one second in litres.

*Numbers are smaller than randomised population for $\mathrm{FEV}_{1}$ and health status because of patient withdrawals, missing assessments, or respiratory infections or exacerbations (affects $\mathrm{FEV}_{1}$ only).

†Zero values are possible in $95 \%$ confidence intervals with non-parametric analyses that show $P$ values $\leqslant 0.05$ because method of calculation of confidence intervals differs from non-parametric test. 


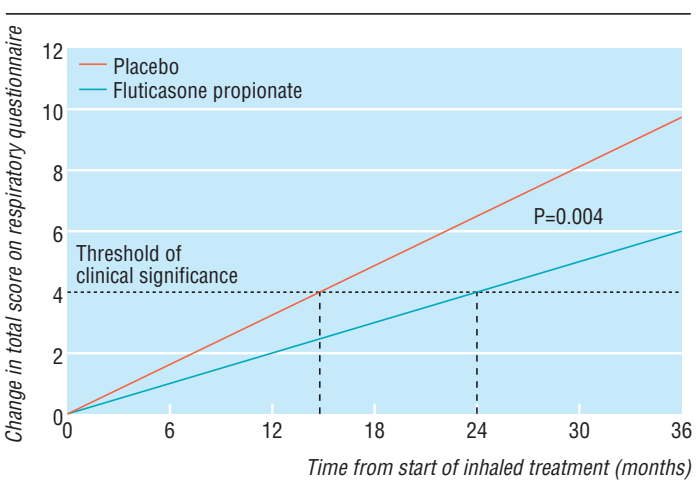

Fig 4 Weighted regressions from random coefficients (mixed) model (see text) to account for the effect of differences in the number of observations between patients, with adjustment for baseline covariates (baseline questionnaire score, age at entry, sex, centre, and smoking during the study)

Table 3 Number of patients with each category of adverse events during double blind period

Fluticasone Placebo $(n=370)$ propionate $(n=372)$

\begin{tabular}{lcc}
\hline Serious adverse events: & & \\
\hline Any event & 148 & 141 \\
\hline Lower respiratory & 101 & 87 \\
\hline Cardiovascular & 44 & 40 \\
\hline Gastrointestinal & 13 & 19 \\
\hline Deaths: & 36 & 32 \\
\hline Total & 6 & 9 \\
\hline Non-malignant respiratory & 12 & 10 \\
\hline Cardiovascular & 14 & 8 \\
\hline Cancers & 4 & 5 \\
\hline Other & 16 & 35 \\
\hline Inhaled glucocorticoid-related events: & 27 & 43 \\
\hline Hoarseness/dysphonia & 24 & 41 \\
\hline Throat irritation & 15 & 27 \\
\hline Candidiasis of mouth/throat & 17 & 9 \\
\hline Events possibly attributed to systemic absorption: & 5 \\
\hline Bruising & 7 & \\
\hline Fractures & 7 & \\
\hline Cataracts
\end{tabular}

${ }^{*}$ Includes ecchymotic rash (1 placebo patient, 8 fluticasone propionate patients).

\section{Discussion}

Inhaled corticosteroids have been used widely in the United Kingdom for the empirical treatment of symptomatic chronic obstructive pulmonary disease, but evidence to support this practice is limited. Unlike early reports, ${ }^{18} 19$ our study in moderate to severe chronic obstructive pulmonary disease found no effect of corticosteroids on the rate of decline in $\mathrm{FEV}_{1}-\mathrm{a}$ finding consistent with two recent budesonide studies in mild disease. ${ }^{910}$ Like Euroscop, a study in continued smokers, ${ }^{10}$ we found a small improvement in $\mathrm{FEV}_{1}$ after bronchodilator at three months, which was maintained throughout the study. The clinical significance of this change in airway function is unclear. Our study also showed no significant relation between corticosteroid trial response and response to long term inhaled corticosteroid.

The exacerbation rate for placebo was similar to that seen in previous reports, ${ }^{20}$ but for fluticasone propionate it was $25 \%$ lower. Precise definition of an exacerbation is difficult in ambulant patients with chronic obstructive pulmonary disease, but, by using the operational approach adopted in ISOLDE, reductions in exacerbation severity were seen in another study of patients with moderately severe disease treated for six months with fluticasone propionate ${ }^{21}$ During the ISOLDE run-in we also observed that withdrawal of inhaled corticosteroids was associated with an increased likelihood of an exacerbation..$^{22}$ These observations suggest that inhaled corticosteroids do modify the risk of symptomatic deterioration in chronic obstructive pulmonary disease.

Assessment of of health status is recognised as an important additional measurement in patients with chronic respiratory disease and is a better predictor of admission to hospital and death within 12 months than $\mathrm{FEV}_{1}{ }^{23}$ The baseline respiratory questionnaire score showed significant impairment, in keeping with other populations with similar reductions in $\mathrm{FEV}_{1}{ }^{13}{ }^{14}$ This study shows for the first time that, like $\mathrm{FEV}_{1}$, health status declines at a measurable rate in patients with moderate to severe chronic obstructive pulmonary disease. Fluticasone propionate significantly reduced this rate of decline, delaying the average time for a clinically important reduction in health status from 15 to 24 months. As the respiratory questionnaire has only a weak correlation with $\mathrm{FEV}_{1},{ }^{5}$ it must be reflecting other disease components other than airflow limitation.

\section{Limitations}

Several factors, including disease severity, comorbidity, and study duration, contributed to the high withdrawal rate. Patients were also actively withdrawn from the study and not subsequently followed up if they experi-

Table 4 Morning serum cortisol concentration (nmol/l) for patients who provided valid data (8 am to 10 am samples only) during double blind period

\begin{tabular}{|c|c|c|c|c|c|c|}
\hline \multirow[b]{2}{*}{ Time point } & \multicolumn{3}{|c|}{ Placebo $(n=370)$} & \multicolumn{3}{|c|}{ Fluticasone propionate ( $n=372$ ) } \\
\hline & $\begin{array}{l}\text { Patients with } \\
\text { valid samples }\end{array}$ & $\begin{array}{l}\text { Geometric mean* } \\
\text { serum cortisol } \\
\text { (CV†) }\end{array}$ & $\begin{array}{c}\text { No }(\%) \text { of patients with } \\
\text { values below normal range } \\
(150-700 \mathrm{nmol} / \mathrm{l})\end{array}$ & $\begin{array}{l}\text { Patients } \\
\text { with valid } \\
\text { samples }\end{array}$ & $\begin{array}{l}\text { Geometric mean } \\
\text { serum cortisol * } \\
\text { (CV†) }\end{array}$ & $\begin{array}{c}\text { No }(\%) \text { of patients with } \\
\text { values below normal range } \\
(150-700 \mathrm{nmol} / \mathrm{l})\end{array}$ \\
\hline Baseline & 265 & $344(33)$ & $5(2)$ & 265 & $353(31)$ & $4(2)$ \\
\hline 6 months & 260 & $345(33)$ & $3(1)$ & 272 & $311(42)$ & $2(1)$ \\
\hline 12 months & 209 & $352(34)$ & $3(1)$ & 238 & $316(45)$ & $13(5)$ \\
\hline 24 months & 136 & $345(34)$ & $1(1)$ & 160 & $303(44)$ & $5(3)$ \\
\hline 36 months & 93 & $354(33)$ & $1(1)$ & 96 & $310(35)$ & $4(4)$ \\
\hline $\begin{array}{l}>1 \text { point during double } \\
\text { blind treatment }\end{array}$ & 299 & - & $4(1)$ & 331 & - & $17(5)$ \\
\hline
\end{tabular}

*Least squares means from analysis of covariance of log transformed serum cortisol concentrations were back transformed to give geometric means. $+C V=$ coefficient of variation $(\%)$ 


\section{What is already known on this topic}

Inhaled corticosteroids are widely prescribed for patients with chronic obstructive pulmonary disease, although there are few studies to support this

A meta-analysis of three small studies showed improvements in $\mathrm{FEV}_{1}$ with high dose beclomethasone dipropionate or budesonide but no benefit from medium dose treatment

In two recent large studies, budesonide in medium dose produced either no benefit or a small initial improvement in $\mathrm{FEV}_{1}$

\section{What this study adds}

This study measured progressive decline in health status of patients with chronic obstructive pulmonary disease rather than just the $\mathrm{FEV}_{1}$

In patients with moderate to severe disease, fluticasone propionate $1 \mathrm{mg}$ daily resulted in fewer exacerbations, a reduced rate of decline in health status, and higher $\mathrm{FEV}_{1}$ values than placebo treatment

Serious side effects were similar to placebo, topical side effects were increased

These data provide a rationale for the use of high dose inhaled corticosteroids in patients with moderate to severe chronic obstructive pulmonary disease

enced frequent exacerbations; this is an acknowledged limitation of the study. The effect of the differential rate of withdrawal from treatment is difficult to quantify, nevertheless it is likely to have led to a conservative estimate of benefit with fluticasone propionate.

Reports of adverse events for each treatment were generally similar, although the incidence of events related to glucocorticoids was slightly higher in the fluticasone propionate group. The incidence of fractures was low $(2 \%)$ and similar to that reported in Euroscop. $^{10}$ No more than $5 \%$ of patients on fluticasone propionate had cortisol concentrations below the normal range at any time during treatment. Similar reassuring data have been reported from a two year placebo controlled study of fluticasone propionate $500 \mu \mathrm{g}$ twice daily in adults with mild asthma. ${ }^{24}$

\section{Conclusions}

We found no benefit of fluticasone propionate on the rate of decline in $\mathrm{FEV}_{1}$, although small improvements in $\mathrm{FEV}_{1}$ were seen. Unlike the two studies in patients with milder disease, where other clinical outcomes were less measurable, ${ }^{9}{ }^{10}$ we found that fluticasone propionate $500 \mu \mathrm{g}$ twice daily significantly reduced exacerbations and the rate of decline in health status. These data provide a rationale for the current practice of using use of inhaled corticosteroids at this dose in patients with moderate to severe chronic obstructive pulmonary disease.

Dr G F A Benfield, Dr M D L Morgan, Dr J C Pounsford, Dr R M Rudd, and Professor S G Spiro provided input into the design of the study. The scientific committee members comprised: Dr G F A Benfield, Professor P M A Calverley, Dr J Daniels, Dr A Greening, Professor G J Gibson, Professor P W Jones, Dr M D L Morgan, Dr R Prescott, Dr J C Pounsford, Dr R M Rudd, Professor D Shale, Professor S G Spiro, Mrs J Waterhouse, Dr J A Wedzicha, and Dr D Weir. The steering committee members were Mrs G Bale, Dr P S Burge, Professor P W Jones, and Dr G F A Benfield. Quality control of spirometry data was supervised by Jonathon Daniels and Geraldine Bale, who also acted as study nurse coordinator. Contributions in recruiting patients and with data collection were provided by Professor J G Ayres, Mrs G Bale, Dr N Barnes, Mrs C Baveystock, Dr G F A Benfield, Ms K Bentley, Dr Birenacki, Ms G Boar, Dr P Bright, Ms M Campbell, Ms P Carpenter, Ms S Cattell, Dr I I Coutts, Dr L Davies, Ms C Dawe, Ms J Dowselt, Ms K Dwyer, Mrs C Evans, Ms N Fasey, Dr A G Fennerty, Dr D Fishwick, Ms H Francis, Dr T Frank, Mrs D Frost, Professor G J Gibson, Dr J Hadcroft, Dr M G Halpin, Mrs O Harvey, Dr P Howard, Dr N A Jarad, Ms JJones, Dr K Lewis, Mrs F Marsh, Mrs N Martin, Dr M D L Morgan, Ms L Morgan, Mrs W McDonald, Ms T Melody, Dr R D H Monie, Dr M F Muers, Dr R Niven, Dr C O'Brien, Ms V O’Dwyer, Ms S Parker, Dr M Peake, Dr W H Perks, Professor C A C Pickering, Dr J C Pounsford, Mrs K Pye, Mr G Rees, Ms A Reid, Ms K Roberts, Mrs C Robertson, Dr R M Rudd, Ms S Rudkin, Mr S Scholey, Dr P Scott, Dr T Seemungal, Ms S Shaldon, Dr C D Sheldon, Ms T Small, Professor S G Spiro, Dr J R Stradling, Ms H Talbot, Mrs J Waterhouse, Mrs L Webber, Dr J A Wedzicha, and Ms M J Wild.

Contributors: PSB and PMAC had the original idea for the present study, helped with the study design, recruited large numbers of patients, advised on data analysis, and helped with the writing of the paper. PSB chaired the scientific committee responsible for coordinating analyses, publications, and substudies. He is also the guarantor of the paper. PMAC chaired the steering committee that facilitated and monitored study progress. PWJ advised on collection and analyses of health status questionnaire data, recruited patients into the study, and helped with the writing of the paper. SS advised on data collection and carried out the health status analyses. JAA analysed the clinical efficacy data. TKM managed data collection and helped with data interpretation and the writing of the paper.

Funding: GlaxoWellcome Research and Development.

Competing interests: PSB has received financial support for research and attending meetings and has received fees for speaking and consulting. He also has shares in GlaxoWellcome. PMAC has received grant support and has spoken at several meetings financially supported by GlaxoWellcome. PWJ has received funds for research and members of staff from GlaxoWellcome. SS has received funds for research and members of staff from GlaxoWellcome.JAA and TKM are both employed by GlaxoWellcome. Fluticasone propionate is manufactured by Allen and Hanburys, which is owned by GlaxoWellcome.

1 Thom TJ. International comparisons in COPD mortality. Am Rev Respir Dis 1989;140:27-34.

2 Murray CJ, Lopez AD. Mortality by cause for eight regions of the world: global burden of disease study. Lancet 1997;349:1269-76.

3 Murray CJL, Lopez AD. Alternative projections of mortality and disability by cause 1990-2020: global burden of disease study. Lancet 1997;349:1498-504.

4 Fletcher CM, Peto R. The natural history of chronic airflow obstruction. BMJ 1978;1:1645-8.

5 Jones PW, Quirk FH, Baveystock CM. The St George's respiratory questionnaire. Respir Med 1991;85(suppl B):25-31.

6 Anthonisen NR, Connett JE, Kiley JP, Altose MD, Bailey WC, Buist AS, et al for the Lung Health Study Research Group. Effects of smoking intervention and the use of an anticholinergic bronchodilator on the rate of decline in $\mathrm{FEV}_{1}$. JAMA 1994;272:1497-505.

7 Callahan CM, Dittus RS, Katz BP. Oral corticosteroid therapy for patients with stable chronic obstructive pulmonary disease. A meta-analysis. Ann Intern Med 1991;114:216-23.

8 Postma DS, Peters I, Steenhuis EJ, Sluiter HJ. Moderately severe chronic airflow obstruction. Can corticosteroids slow down obstruction? Eur Respir J 1998;1:22-6.

9 Vestbo J, Sorensen T, Lange P, Brix A, Torre P, Viskum K. Long-term effect of inhaled budesonide in mild and moderate chronic obstructive pulmonary disease: a randomised controlled trial. Lancet 1999;353:1819-23

10 Pauwels RA, Lofdahl CG, Laitinen LA, Schouten JP, Postma DS, Pride $\mathrm{NB}$, et al. Long-term treatment with inhaled budesonide in persons with mild chronic obstructive pulmonary disease who continue smoking. N Engl J Med 1999;340:1948-53.

11 American Thoracic Society. Statement: standardization of spirometry, 1987 update. Am Rev Respir Dis 1987;136:1285-98.

12 Enright PL, Johnson LR, Connett JE, Voelker H, Buist AS. Spirometry in the lung health study. 1. Methods and quality control. Am Rev Respir Dis $1991 ; 143: 1215-23$ 
13 Jones PW, Quirk FH, Baveystock CM, Littlejohns P. A self-complete measure of health status for chronic airflow limitation. The St George's respiratory questionnaire. Am Rev Respir Dis 1992;145:1321-7.

14 Meecham Jones DJ, Paul EA, Jones PW, Wedzicha JA. Nasal pressure support ventilation plus oxygen compared with oxygen therapy alone in hypercapnic COPD. Am J Respir Crit Care Med 1995;152:538-44.

15 Goldstein H. Multilevel statistical models. 2nd ed. London: Edward Arnold, 1995.

16 Bryk AS, Raudenbush SW. Hierarchical linear models. London: Sage Publications, 1992.

17 Van Elteren PH. On the combination of independent two-sample tests of Wilcoxon. Bull Int Stat Inst 1960;37:351-61.

18 Dompeling E, van Schayck CP, van Grunsven PM, van Herwaarden CL Akkermans R, Molema J, et al. Slowing the deterioration of asthma and chronic obstructive pulmonary disease observed during bronchodilator therapy by adding inhaled corticosteroids. A 4 -year prospective study. Ann Intern Med 1993;118:770-8.

19 an Grunsven PM, van Schayck CP, Derenne JP, Kerstjens HA, Renkema TE, Postma DS, et al. Long term effects of inhaled corticosteroids in chronic obstructive pulmonary disease: a meta-analysis. Thorax $1999 ; 54: 7-14$.
20 Seemungal TA, Donaldson GC, Paul EA, Bestall JC, Jeffries DJ, Wedzicha JA. Effect of exacerbation on quality of life in patients with chroni obstructive pulmonary disease. Am J Respir Crit Care Med 1998;157:1418-

21 Paggiaro PL, Dahle R, Bakran I, Frith L, Hollingworth K, Efthimiou J Multicentre randomised placebo-controlled trial of inhaled fluticasone propionate in patients with chronic obstructive pulmonary disease. propionate in patients

22 Jarad NA, Wedzicha JA, Burge PS, Calverley PMA for the ISOLDE study group. An observational study of inhaled corticosteroid withdrawal in stable chronic obstructive pulmonary disease. Respir Med 1999;93:161-6.

23 Osman LM, Godden DJ, Friend JAR, Legge JS, Douglas JG. Quality of life and hospital re-admission in patients with chronic obstructive pulmonary disease. Thorax 1997;52:67-71.

24 Li JTC, Ford LB, Chevinsky P, Weisberg SC, Kellerman DJ, Faulkner KG, et al. Fluticasone propionate powder and lack of clinically significant effects on hypothalamic-pituitary-adrenal axis and bone mineral density over 2 years in adults with mild asthma. J Allergy Clin Immuno $1999 ; 103: 1062-8$

(Accepted 7 February 2000)

\title{
Comparing health inequality in men and women: prospective study of mortality 1986-96
}

\author{
Amanda Sacker, David Firth, Ray Fitzpatrick, Kevin Lynch, Mel Bartley
}

\begin{abstract}
Objectives To study prospectively the differences in health inequality in men and women from 1986-96 using the Office for National Statistics' longitudinal study and new socioeconomic classification. To assess the relative importance of social class (based on employment characteristics) and social position according to the general social advantage of the household to mortality risk in men and women. Design Prospective study.

Setting England and Wales.
\end{abstract}

Subjects Men and women of working age at the time of the 1981 census, with a recorded occupation.

Main outcome measures Mortality.

Results In men, social class based on employment relations, measured according to the Office for National Statistics' socioeconomic classification, was the most important influence on mortality. In women, social class based on individual employment relations and conditions showed only a weak gradient. Large differences in risk of mortality in women were found, however, when social position was measured according to the general social advantage in the household. Conclusions Comparisons of the extent of health inequality in men and women are affected by the measures of social inequality used. For women, even those in paid work, classifications based on characteristics of the employment situation may give a considerable underestimate. The Office for National Statistics' new measure of socioeconomic position is useful for assessing health inequality in men, but in women a more important predictor of mortality is inequality in general social advantage of the household.

\section{Introduction}

Social variation in morbidity and mortality in women whose social position is measured according to their own occupation is often found to be less than that of men. ${ }^{1-4}$ The extent of social inequality in women's health is known to be particularly sensitive to the way in which inequality is defined and measured. ${ }^{156}$ When women's social position is classified according to the occupation of their male partners, male and female health gradients are more similar. ${ }^{78}$ In estimates of health inequality there is comparatively little discussion of these apparent sex differences.

It is now possible to study sex differences in health inequality with distinct validated measures of social position and advantage, one based on relations and conditions of employment and the other on material cultural aspects of lifestyle outside the workplace. The Office for National Statistics (ONS) has recently adopted a new measure of social inequality: the ONS socioeconomic classification, for use in the 2001 census and official surveys. ${ }^{9}$ This measure allocates occupations to social classes on the basis of aspects of the work situation, in particular the extent to which members of an occupation have control over their own work and that of others.

The other measure is the Cambridge scale, which is based on general social and material advantage and lifestyle as reflected in choices of friendship. ${ }^{10-12}$ Both measures are being increasingly used in health studies and have been found to be related to mortality, morbidity, and health related behaviour. ${ }^{13-18}$

We aimed to determine whether social gradients in mortality in women in England and Wales during 1986-96 were less noticeable than in men, and whether this depended on the measure of social inequality used.

\section{Subjects and methods}

\section{Sample}

The ONS longitudinal study is an approximate $1 \%$ sample of the population of England and Wales. Sampling was begun at the time of the 1971 census when all those born on any one of four days in the year were entered into the dataset. The study is regularly updated to include new members born on any one of the four designated dates. ${ }^{19}$ Vital events including mortality are
Editorial by Vågerö

Department of Epidemiology and Public Health, Royal Free and University College London Medical School,

London

WC1E 6BT

Amanda Sacker senior research fellow Mel Bartley principal research fellow

Nuffield College, Oxford OX1 1NF

David Firth senior fellow in statistics for the social sciences

Institute of Health Sciences, University of Oxford, Oxford OX3 7LF

Ray Fitzpatrick professor of public health and primary care

continued over

BMJ 2000;320:1303-7

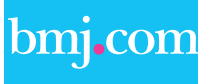

Some occupations according to ONS classes and the Cambridge scale appear on the $B M J$ 's website 